\title{
Oktant morski Isaaca Newtona
}

\section{Isaac Newton's Marine Octant}

Isaac Newton is known primarily as an outstanding mathematician and physicist. Less known are his interests in alchemy, theology, and history. Yet, we still know very little about his interest in engineering and about how he designed and created several scientific instruments (e.g. a variant of the reflecting telescope, a variant of the rotary slide rule). Among them, there is also a navigational octant built by Newton in 1699 . This device is an example of an ingenious solution in the field of early modern catadioptrical instruments.

Keywords: Isaac Newton, octant, navigational instruments in the $17^{\text {th }}$ century Słowa kluczowe: Isaac Newton, oktant, przyrządy nawigacyjne w XVII wieku

Isaaca Newtona (1642-1727) znamy przede wszystkim jako wybitnego matematyka i fizyka, jednego z największych umysłów wszechczasów. Mniej znane są jego równie szerokie zainteresowania alchemią i teologią, a także wczesną historią chrześcijaństwa, chronologią i proroctwami biblijnymi. W chwili obecnej, jak się wydaje, jednym z najmniej znanych i rozpoznanych obszarów aktywności wielkiego Anglika pozostają wciąż jego dokonania na polu rozwiązań technicznych i inżynierskich, którymi - jak się okazuje - fascynował się od najmłodszych lat ${ }^{1}$. Przypuszczalnie najbardziej znanym przejawem tych zainteresowań było samodzielne skonstruowanie przez Newtona w latach 1668-1671 trzech wariantów teleskopu zwierciadłowego, przy czym drugi z tych przyrządów przyczynił się do włączenia autora Matematycznych zasad filozofii przyrody (Philosophiae naturalis principia mathematica) w poczet członków londyńskiego Towarzystwa Królewskiego $^{2}$. Nie było to jednak jedyne urządzenie techniczne zaprojektowane i skonstruowane przez niego.

1 Na temat młodzieńczych zainteresowań Newtona techniką zob.: E.N. da C. Andrade, Two Historical Notes, „Nature" t. 135, 1935, nr 3410, s. 359-360; G.L. Huxley, Two Newtonian Studies, I. Newton's Boyhood Interests, "Harvard Library Bulletin" t. 13, 1959, s. 348-354, R.S. Westfall, Never at Rest. A Biography of Isaac Newton, Cambridge 1980, s. 60-63; F. Manuel, Portret Izaaka Newtona, Warszawa 1998, s. 50-64.

2 Dzieje trzech wariantów newtonowskiego teleskopu odbiciowego (zwierciadłowego, reflektora) omówione są szczegółowo w pracy: A.D.C. Simpson, The Early Development of the Reflecting Telescope in Britain, nieopublikowana praca doktorska, University of Edinburg 1981, s. 64-148. 
Jednym z kolejnych rozwiązań technicznych zaproponowanych przez angielskiego uczonego było zbudowanie około 1699 r. katadioptrycznego ${ }^{3}$ przyrządu przeznaczonego do nawigacji w żegludze, nazywanego dziś oktantem ${ }^{4}$ morskim lub - z racji wykorzystanej w nim optyki - oktantem odbiciowym. W dotychczasowej literaturze z zakresu historii nauki i techniki temat oktantu Newtona pojawiał się sporadycznie i bez pogłębionego oraz obszerniejszego potraktowania, zwykle w związku z omawianiem ewolucji nowożytnych przyrządów nawigacyjnych oraz wzmożonymi od drugiej połowy XVII w. wysiłkami nad opracowaniem skutecznej metody wyznaczania w warunkach morskich długości geograficznej. W przypadku Newtona wysiłki te wiązały się również z pracami nad teorią ruchu Księżyca, gdyż jedną z bardziej obiecujących w nawigacji metod wyznaczenia długości geograficznej była tzw. metoda odległości księżycowych. Przy tej okazji na bliższą uwagę zasługuje talent rzemieślniczy autora Zasad oraz umiejętność łączenia rozważań teoretycznych z aktualnymi społecznymi potrzebami praktycznymi.

Ze współczesnych autorów podejmujących w jakimś, choć bardzo ograniczonym zakresie, temat oktantu newtonowskiego należy najpierw wymienić R.K. Mertona i E.G.R. Taylor ${ }^{5}$. R.S. Westfall wspomniał o tym przyrządzie nawigacyjnym w swojej niemal tysiącstronicowej, zwanej też ostateczną (ultimate), biografii Newtona jedynie w ramach trzech krótkich i oddzielnych akapitów ${ }^{6}$. Po niespełna dwie strony tekstu poświęcili oktantowi Newtona tacy badacze jak: C.H. Cotter, H.C. Freiesleben, A.D.C. Simpson, J. Bennett i W.F.J. Mörzer Bruyns, przy czym dwaj pierwsi autorzy oparli się częściowo na niektórych informacjach zawartych we wspomnianej pracy Taylor, z kolei Mörzer Bruyns na pracach Cottera i Bennetta7. Natomiast Simpson, zajmując się w swoim opracowaniu zupełnie inną kwestią (wczesną ewolucją teleskopu zwierciadłowego), jako jedyny usiłował przy tej okazji przynajmniej hipotetycznie odpowiedzieć na pytanie, jakie mogły być losy oktantu newtonowskiego po jego prezentacji na forum Towarzystwa Królewskiego. Jak widać z tego krótkiego przeglądu literatury, nie dysponujemy jak dotąd bardziej wyczerpującym opracowaniem tematu przyrządu nawigacyjnego zaprojektowanego i skonstruowanego przez autora Zasad.

3 Przyrząd katadioptryczny łączył w sobie elementy dioptryczne (oparte na optyce soczewkowej) i katoptryczne (oparte na optyce zwierciadeł).

4 Nazwę „oktant” wprowadził po raz pierwszy w swoim artykule z 1731 r. John Hadley, o którego przyrządach nawigacyjnych będzie mowa w dalszej części tego artykułu. Oznaczał on wtedy raczej ósmą część koła podziałowego (łuk), aniżeli osobny przyrząd nawigacyjny; J. Hadley, The Description of a New Instrument for Taking Angles, „Philosophical Transactions of the Royal Society of London” t. 37, 1731, nr 420, s. 150. W niniejszym artykule przenosimy umownie tę nazwę także na przyrząd katadioptryczny Newtona.

5 Merton wspomniał jedynie o zbudowanym przez Newtona „sekstansie” (w istocie nazwanym błędnie, gdyż instrument ten był oparty na łuku o kącie 45 stopni, a więc był oktantem) w swoim znanych tekście z 1939 r. Science and the Economy of Seventeenth Century England, przy okazji omówienia znaczenia dla nauki angielskiej poszukiwań skutecznej metody wyznaczania długości geograficznej; zob. polskojęzyczny przekład: R.K. Merton, Teoria socjologiczna i struktura społeczna, tłum. E. Morawska, Warszawa 1982, s. 639-651. E. Taylor z kolei wymieniła oktant newtonowski głównie w perspektywie projektowanych i produkowanych przyrządów matematycznych w siedemnastowiecznej Anglii; E.G.R. Taylor, The Mathematical Practitioners of Tudor and Stuart England, London 1954, s. 251.

6 R.S. Westfall, op. cit., s. 576, 589, 629.

7 Zob.: C.H. Cotter, The Mariner's Sextant and the Royal Society, "Notes and Records of the Royal Society of London" t. 33, 1978, nr 1, s. 30-31; H.C. Freiesleben, Newton's Quadrant for Navigation, "Vistas in Astronomy" t. 22, 1979, nr 4, s. 518-521; J. Bennett, Catadioptrics and Commerce in Eighteenth-Century London, "History of Science" t. 44, 2006, nr 2, s. 252-253; W.F.J. Mörzer Bruyns, Sextants at Greenwich: A Catalogue of the Mariner's Quadrants, Mariner's Astrolabes, Cross-staffs, Backstaffs, Octants, Sextants, Quadrants, [...] in the National Maritime Museum, Greenwich, Oxford 2009, s. 23-24; A.D.C. Simpson, op. cit., s. 207-208. 
W niniejszym opracowaniu zostaną przybliżone i pogłębione dzieje nawigacyjnego przyrządu obserwacyjno-pomiarowego zaprojektowanego przez Newtona, zarówno z uwzględnieniem kontekstu innowacyjnych rozwiązań tego instrumentarium w XVII w. i na początku XVIII w., jak i w perspektywie zmagań środowiska angielskich matematyków, wytwórców przyrządów oraz kręgów żeglarskich nad opracowaniem skutecznej metody określania długości geograficznej na morzu. Ponieważ w omawianym okresie oktant Newtona nie był jedynym przyrządem tego rodzaju, zostanie on porównany z innymi, zbliżonymi konstrukcyjnie i funkcjonalnie projektami, zaproponowanymi w ciągu kilkudziesięciu lat przez Roberta Hooke'a, Edmonda Halleya i Johna Hadleya.

Stosunkowo skromny materiał źródłowy dotyczący bezpośrednio lub pośrednio oktantu Newtona, na którym opiera się to opracowanie, pochodzi z Biblioteki Uniwersyteckiej w Cambridge, archiwów w King's College (Cambridge) oraz londyńskiego Towarzystwa Królewskiego, a także z wydanych drukiem prac samego Newtona oraz jego korespondencji.

\section{Newton, admiralicja i problem długości geograficznej}

Ponieważ w artykule interesuje nas przede wszystkim rok 1699, w którym Newton zaprezentował na forum Towarzystwa Królewskiego swój przyrząd nawigacyjny, krótko przybliżymy kontekst historyczny tego wydarzenia. W tym czasie angielski uczony od trzech lat był nadzorcą (warden) londyńskiej Mennicy Królewskiej, a już niebawem, w styczniu 1700 r. został jej kuratorem (master). Jego praca nie miała wtedy wiele wspólnego z nauką: dbając o interesy króla, Newton m.in. ścigał fałszerzy i tzw. obcinaczy monet oraz nadzorował, zakończone w czerwcu 1699 r., wielkie przedsięwzięcie odnowy angielskiej monety (Great Recoinage) ${ }^{8}$. W styczniu tego roku starł się kolejny raz z astronomem królewskim Johnem Flamsteedem (1646-1719) w sprawie wymieniania przez tego ostatniego publicznie nazwiska Newtona i jego dotychczasowych porażek w stworzeniu teorii ruchu Księżyca ${ }^{9}$. Na domiar w tym samym miesiącu szwajcarski przyjaciel autora Zasad Nicolas Fatio de Duillier (1664-1753) ogłosił pracę sugerującą pierwszeństwo Newtona przed Leibnizem w odkryciu rachunku różniczkowego i całkowego (calculus) ${ }^{10}$. W tym nawale obowiązków i spiętrzonych sporów naukowych angielski uczony pozostał jako ekspert otwarty na potrzeby instytucji państwowych.

W dniu 12 sierpnia 1699 r. Newton napisał list do Kontrolera Marynarki angielskiej (inaczej: przewodniczącego Urzędu Marynarki) sir Richarda Haddocka (1629-1715), w którym informował o otrzymaniu innego listu, od Sekretarza Admiralicji Josiaha Burchetta (ok. 1666-1746) z jego sugestią przedyskutowania propozycji dotyczącej „znajdowania długości geograficznej na morzu" (finding the Longitude). W swoim liście Newton wyraził

8 Zob. T. Levenson, Newton and the Counterfeiter. The Unknown Detective Career of the World's Greatest Scientist, London 2011, s. 143

9 List Newtona do Flamsteeda z 6 I 1699 r.; The Correspondence of Isaac Newton, vol. 4, 1694-1709, wyd. James F. Scott, Cambridge 1967, s. 296. Newton nie życzył sobie wspominania jego nazwiska i niezbyt udanych prac nad teorią Księżyca, aby nie wzbudzać podejrzeń o zaniedbywanie przez niego obowiązków urzędniczych w Mennicy.

10 N. Fatio de Duillier, Lineae brevissimi descensus investigate geometrica duplex, Londini 1699. Por. F.E. Manuel, op. cit., s. 340; s. 464-465, przyp. 18. 
gotowość do spotkania się w tej sprawie z Haddockiem oraz admirałem sir Cloudesleyem Shovelem (1650-1707) ${ }^{11}$. Cztery dni później autor Zasad pojawił się na posiedzeniu Towarzystwa Królewskiego, na którym przedstawił zbudowany przez siebie przyrząd nawigacyjny, służący do wyznaczania długości geograficznej na morzu. Sekretarz Towarzystwa Hans Sloane (1660-1753) w protokołach posiedzeń umieścił o tym następującą notatkę:

Pan Newton pokazał, obmyślony (contrived) przez siebie, nowy przyrząd do obserwacji [na morzu] ${ }^{12}$ długości geograficznej [z położenia Księżyca i gwiazd], będący starym przyrządem uwolnionym od kilku usterek, za pomocą którego pan Halley, mimo to, znajdował długość geograficzną lepiej, aniżeli żeglarze za pomocą innych metod $^{13}$.

Należy od razu zauważyć, że spośród wymienionych na wstępie, niezwykle zwięzłych skądinąd omówień kwestii wynalazku oktantu odbiciowego przez Newtona o jego motywacji, nazwijmy to - praktyczno-społecznej, do budowy tego przyrządu ze strony marynarki angielskiej wzmiankuje jedynie Westfall ${ }^{14}$, który z kolei dalej w ogóle nie rozwija zarówno tej kwestii, jak i znaczenia projektu technicznego autora Zasad. Z drugiej strony pozostali autorzy dotychczasowych opracowań poświęconych temu przyrządowi nawigacyjnemu skupili się w nich wyłącznie na aspektach technicznych bez wnikania w kontekst gospodarczo-handlowy i militarny jego powstania, zwłaszcza w realiach XVII-wiecznej Anglii. Co więcej, nawet mimo podjęcia kwestii budowy i funkcji oktantu odbiciowego Newtona żaden z nich nie próbował roztrząsać szerszego i intrygującego zagadnienia jego zainteresowań projektowaniem przyrządów naukowych ${ }^{15}$.

Powracając do listu skierowanego do Newtona, należy również dodać, że co prawda nic nie wiadomo, czy doszło do jego spotkania z przewodniczącym Urzędu Marynarki Haddockiem i admirałem Shovelem, jednak przypuszczalnie prezentacja przyrządu miała jakiś związek, choćby ze względu na bliskość czasową, z listem do Haddocka. Tak czy inaczej sprawa dotyczyła kwestii palącej od dziesięcioleci, żeby nie powiedzieć - od wieków, a mianowicie problemu znalezienia skutecznej metody określania długości geograficznej na morzu.

Problem wyznaczania długości geograficznej na morzu, a co za tym idzie położenia żeglujących okrętów, stał się w XVII w., zwłaszcza dla ówczesnych potęg morskich i kolonialnych, w tym oczywiście Anglii, poważną sprawą wagi państwowej. Na skutek strat związanych z zatonięciem licznych zagubionych czy zniszczonych jednostek floty wojennej, handlowej lub rybackiej, cierpiał niejednokrotnie skarbiec, prestiż gospodarczy i polityczny, a także morale marynarskie. Wyznaczenie szerokości geograficznej na podstawie położenia Słońca nad horyzontem w dzień lub gwiazd w nocy nie stanowiło

11 The Correspondence of Isaac Newton, vol. 4, s. 314. Por. również: R.S. Westfall, op. cit., s. 589.

12 W nawiasach kwadratowych są słowa dopisane później do pierwotnego tekstu protokołu.

13 Royal Society Archive, London, Sir Hans Sloane's Minutes Books of the Royal Society Meetings, 1699-1702, [RSA, SM], sygn. MS 577, k. 19v.

14 R.S. Westfall, op. cit., s. 589. Używa on także nieco mylącej nazwy sextant. Nie należy wszakże zapominać, że nazwa łacińska sextans funkcjonowała w piśmiennictwie, w odniesieniu do przyrządów astrometrycznych o rozwartości łuku 60 stopni co najmniej od czasów Tychona Brahego (1546-1601); por. Z. Šíma, Prague Sextants of Tycho Brahe, "Annals of Science" t. 50, 1993, nr 3, s. 445-453; E. Weekley, An Etymological Dictionary of Modern English, vol. 2, L-Z, New York 2012, s. 1323.

15 Newton nie tylko budował teleskopy zwierciadłowe i skonstruował samodzielnie oktant morski, lecz także był twórcą wariantu obrotowego suwaka logarytmicznego i przyrządu do wykreślania krzywych stożkowych. 
problemu ${ }^{16}$, ale pozwalało jedynie na żeglowanie bez obaw wzdłuż określonego równoleżnika. W przypadku wyznaczania długości geograficznej niezbędne było określenie różnicy czasu lokalnego (słonecznego) mierzonego dla miejsca obserwacji i dla południka odniesienia. Z tej różnicy nawigator obliczał długość geograficzną i zarazem dokładne położenie statku.

Od czasu tzw. wielkich odkryć geograficznych i zarazem niespotykanego w przeszłości rozwoju wypraw drogą morską, niestrudzenie poszukiwano skutecznej metody wyznaczania długości geograficznej. Wykorzystywane metody były różne, od sygnałowych (na podstawie salw armatnich, a nawet głośnego ujadania okaleczonych psów na specjalnych statkach zakotwiczonych w znanych miejscach na płytszych wodach), po astronomiczne (np. sugerowane przez Galileusza obserwacje czasu zaćmień księżyców Jowisza) ${ }^{17}$. Jedną z metod astronomicznych była wymyślona przez niemieckiego astronoma i wytwórcę przyrządów pomiarowych Johannesa Wernera (1468-1522) i ogłoszona w 1514 r., polegająca na obserwacji położenia Księżyca na tle bliskich jego wędrówce gwiazd stałych (lub w dzień, na obserwacji jego wędrówki w pobliżu Słońca) ${ }^{18}$. Metoda ta została potem nazwana metodą odległości księżycowych i konstruując swój przyrząd nawigacyjny, Newton miał przede wszystkim na uwadze ten właśnie sposób wyznaczania, tak upragnionej przez kapitanów statków, długości geograficznej.

Jednak sam przyrząd nawigacyjny, pozwalający na pomiar odległości Księżyca od gwiazd stałych lub Słońca, był tylko jednym z istotnych elementów tej metody astronomicznej. Innym niezbędnym elementem było wykonanie dokładnego katalogu gwiazd, zwłaszcza tych napotykanych w swojej wędrówce przez Księżyc. W końcu trzecim elementem było sporządzenie tablic przewidywanego ruchu samego Księżyca ${ }^{19}$. Jak wiadomo, w przypadku tej ostatniej kwestii do zbudowania teorii ruchu Księżyca swoją rękę, a właściwie swój umysł matematyczny, przyłożył w znacznym stopniu sam Newton. Ruch Księżyca był dla niego zarówno jedną z ważniejszych inspiracji w powstaniu nowej teorii grawitacji, jak i rodzajem jej sprawdzianu w różnych okresach jej tworzenia i doskonalenia ${ }^{20}$. Wiadomo również, że w pełni zadowalającej teorii ruchu Księżyca autor Zasad nigdy nie stworzył, choć w roku prezentacji na forum Towarzystwa Królewskiego swojego oktantu zakończył również prace nad raczej schematem algorytmicznym, niż teorią dynamiczną (opartą na swojej teorii grawitacji) ruchu Księżyca ${ }^{21}$. Po części winą za własne niepowodzenia obarczał nie tylko same trudności matematyczne, lecz także wieloletnie -

16 Do tego celu służyły starsze astrolabia i kwadranty morskie oraz nowsze instrumenty, takie jak back-staff oraz cross-staff. Te ostatnie zostaną omówione w dalszej części tego artykułu.

17 Dzieje poszukiwań metody wyznaczania długości geograficznej na morzu przedstawia barwnie w swojej popularnej książce: D. Sobel, W poszukiwaniu długości geograficznej, tłum. J. Bieroń, Poznań 1998. Zob. także The Quest for Longitude, red. W.J.H. Andrewes, Cambridge, Mass. 1996.

18 J. Werner, Nova translatio primi libri geographiae Cl. Ptolomaei [...], Nürnberg 1514.

19 D. Sobel, op. cit., s. 22-23, 66.

20 Por. R.S. Westfall, op. cit., s. 540-550; J. Włodarczyk, Księżyc w nauce i kulturze Zachodu, Poznań 2012, s. 157167. Jak zanotował John Conduitt, Newton miał wyznać Johnowi Machinowi (1686-1751), że „nigdy głowa nie boli go tak bardzo, jak wtedy, gdy zajmuje się ruchem Księżyca”; King's College, Cambridge, UK, Keynes [Keynes Collection], MS 130.07, k. 6v; także w: The Newton Project, red. Rob lliffe, Scott Mandelbrote, Faculty of History, Oxford, UK, www.newtonproject.ox.ac.uk [dostęp 14.10.2019].

21 Newton opublikował ją w wersji anglojęzycznej pod tytułem: A New and Most Accurate Theory of the Moon's Motion [...], London 1702 oraz łacińskiej jako dodatek do pracy Davida Gregory'ego, Astronomiae Phisicae at Geometricae Elementa, Oxoniae 1702, s. 332-336 (Lunae Theoria Newtoniana). Zob. także: A.R. Hall, Isaac Newton: Adventurer in Thought, Cambridge 1992, s. 273. 
jak sam uważał - ociąganie się z dostarczeniem wyników obserwacji Księżyca ówczesnego astronoma królewskiego Flamsteeda 22 .

Warto również na koniec tej części niniejszego artykułu zwrócić uwagę na to, że w odniesieniu do teoretycznych prac Newtona nad ruchem Księżyca, jak i próby praktycznej zbudowania przyrządu nawigacyjnego, mającego na celu pomiary odległości księżycowych, niepoślednią rolę odgrywał klimat panujący w drugiej połowie XVII w. w kręgach londyńskiego Towarzystwa Królewskiego. Tak pierwsze zalecenia tego gremium, założonego w 1660 r., jak i pierwsze numery wydawanego przez nie czasopisma Philosophical Transactions, podejmowały kwestię koniecznych prac nad stworzeniem skutecznej metody wyznaczania długości geograficznej w warunkach morskich ${ }^{23}$. Zarówno w dyskusjach na forum Towarzystwa, jak i na łamach Transactions panowała w tym okresie owocna konkurencja i zarazem spór o wyższość i większą skuteczność proponowanych metod jej wyznaczania. Poszczególne metody miały zarówno swoich zwolenników, jak i przeciwników. I tak nad metodą zegarów wahadłowych pracowali m.in. C. Huygens i R. Hooke - ówczesny kurator eksperymentów Towarzystwa; nad metodą obserwacji zaćmień księżyców Jowisza pracował G.D. Cassini, ale także pierwszy Astronom Królewski Flamsteed i Halley; nad metodą odległości księżycowych Newton, Halley i Flamsteed; a nad metodą wykorzystującą zjawisko magnetyzmu ziemskiego i kompas m.in. C. Wren i Halley. Obok tych bardziej znanych wówczas i dziś badaczy swój wkład miało wtedy również wielu, często mało znanych rzemieślników, kapitanów marynarki, podróżników, handlowców i przedsiębiorców ${ }^{24}$.

\section{Oktant katadioptryczny a inne nowożytne przyrządy nawigacyjne}

Powróćmy do samego przyrządu nawigacyjnego skonstruowanego przez Newtona. Z przytoczonego powyżej krótkiego zapisu Sloane'a dotyczącego prezentacji tego przyrządu na forum Towarzystwa Królewskiego nic nie dowiadujemy się o jego budowie i parametrach. Dopiero czterdzieści trzy lata później w papierach pozostawionych przez przyjaciela Newtona Edmonda Halleya (1656-1742) w Obserwatorium Królewskim w Greenwich egzekutorzy jego testamentu natknęli się na krótki opis i ilustrację urządzenia (Ryc. 1), które - jak się okazało - odnosiły się do przyrządu prezentowanego przez autora Zasad w 1699 r. $^{25}$

22 Zob. N. Kollerstrom, Newton's Forgotten Lunar Theory: His Contribution to the Quest for Longitude, Santa Fe 2000; N. Kollerstrom, B.D. Yallop, Flamsteed's Lunar Data, 1692-95, Sent to Newton, „Journal for the History of Astronomy" t. 26, 1995, nr 3, s. 237-246. Flamsteed był pierwszym astronomem królewskim, który pracował w zbudowanym w 1675 r. obserwatorium w Greenwich (zaprojektowanym przez Christophera Wrena). Głównym celem obserwatorium były prace nad znalezieniem skutecznej astronomicznej metody wyznaczania długości geograficznej.

23 Por. M.[R.] Holmes, A Narrative concerning the Success of Pendulum Watches at See for the Longitude, „Philosophical Transactions" t. 1, 1665, s. 52-58. Robert Holmes (ok. 1622-1692) nie był uczonym, lecz kapitanem marynarki angielskiej.

24 R.K. Merton, op. cit., s. 639-644. Zob. także: M.S. Mahoney, Longitude in the Context of the History of Science, [w:] The Quest for Longitude, red. W.J.H. Andrewes, Cambridge, Mass. 1996, s. 67.

25 I. Newton, A True Copy of a Paper Found, in the Hand Writing of Sir Isaac Newton, among the Papers of the Late Dr. Halley, Containing a Description of an Instrument for Observing the Moon's Distance from the Fixt Stars at Sea, „Philosophical Transactions of the Royal Society of London” t. 42, 1742, nr 465, s. 155-156. Tekst opisu przyrządu Newtona został odczytany na posiedzeniu Towarzystwa Królewskiego 28 października 1742 r. 
Z dokumentacji odnalezionej u Halleya wynikało, że przyrząd wykonany był z płyty mosiężnej o kształcie łuku, o rozwartości 45 stopni kątowych (stąd częsta jego nazwa - oktant, nawiązująca do jednej ósmej kąta pełnego). Łuk został podzielony przy wierzchołku na 90 jednostek, co ze względu na całkowicie nowatorski układ dwóch zwierciadeł płaskich umieszczonych w środku łuku pozwalało na wykonywanie pomiarów odległości kątowych do 90 stopni $^{26} z$ dokładnością do 1/12 minuty kątowej, czyli 5 sekund kątowych ${ }^{27}$. Wzdłuż jednego $\mathrm{z}$ ramion łuku, w odcinku od punktu zerowego podziałki do środka łuku, została umieszczona nieruchoma lunetka celownicza (perspicil) długości 3 lub 4 stóp (90 lub $120 \mathrm{~cm})^{28}$, przed którą znajdowało się pierwsze zwierciadło. Obok, w środku łuku znajdował się ruchomy wskaźnik (index) z umieszczonym na nim drugim, równoległym do pierwszego zwierciadłem (także ruchomym). Pomiar odległości, np. między określoną gwiazdą a Księżycem, polegał na dostrzeżeniu gwiazdy przez lunetkę celowniczą (przy jednym zwierciadle) i Księżyca dzięki drugiemu zwierciadłu, rzucającemu jego ob-

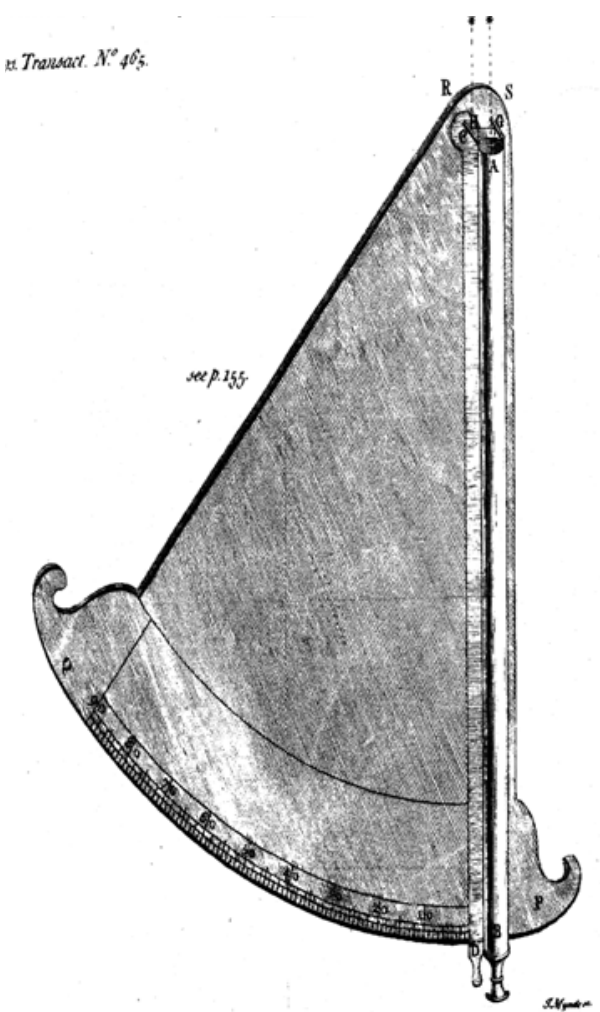

Ryc. 1. Przyrząd nawigacyjny Newtona (Źródło: I. Newton, A True Copy of a Paper Found, in the Hand Writing of Sir Isaac Newton, among the Papers of the Late Dr. Halley, Containing a Description of an Instrument for Observing the Moon's Distance from the Fixt Stars at Sea, "Philosophical Transactions of the Royal Society of London" t. 42, 1742 , nr 465, s. 155-156). raz na pierwsze. Przez obrót wskaźnika ze zwierciadłem należało doprowadzić do „dotknięcia” obrazem gwiazdy obrazu brzegu tarczy Księżyca. Wtedy odległość między tymi obiektami należało odczytać za pomocą wskaźnika na podziałce kątoweje ${ }^{29}$.

26 Stąd można także spotkać się z nazwą „kwadrant Newtona”.

27 Taka dokładność była możliwa do uzyskania dzięki zastosowaniu metody tzw. podziałki diagonalnej (Diagonal Scale); por. I. Newton, A True Copy of a Paper, s. 155. Na temat samej tej metody, wynalezionej przez Tychona Brahego zob. np. J. Rodzeń, Na tropie widma. Geneza i ewolucja spektroskopu optycznego w latach 1810-1860, Kraków 2013, s. 389-390.

28 Stosunkowo duża długość lunetki celowniczej miała przypuszczalnie na celu wyeliminowanie w czasie obserwacji obiektów astronomicznych skutków aberracji chromatycznej. Stosowano wtedy soczewki obiektywowe i okularowe o dużej krzywiźnie, co zwiększało długość lunetki i zarazem całego instrumentu. Pokaźne rozmiary całego przyrządu sprzyjały także wykonaniu dokładniejszego podziału łuku mosiężnego.

29 Było to możliwe mimo kołysania statku na morzu, gdyż odległość między Księżycem a gwiazdą pozostawała niezmienna (the Moon and Star will move together); I. Newton, A True Copy of a Paper, s. 156. Przyrząd mógł służyć nie tylko do wyznaczania długości geograficznej, ale również szerokości geograficznej, obliczanej z wysokości Słońca lub gwiazd nad horyzontem. 


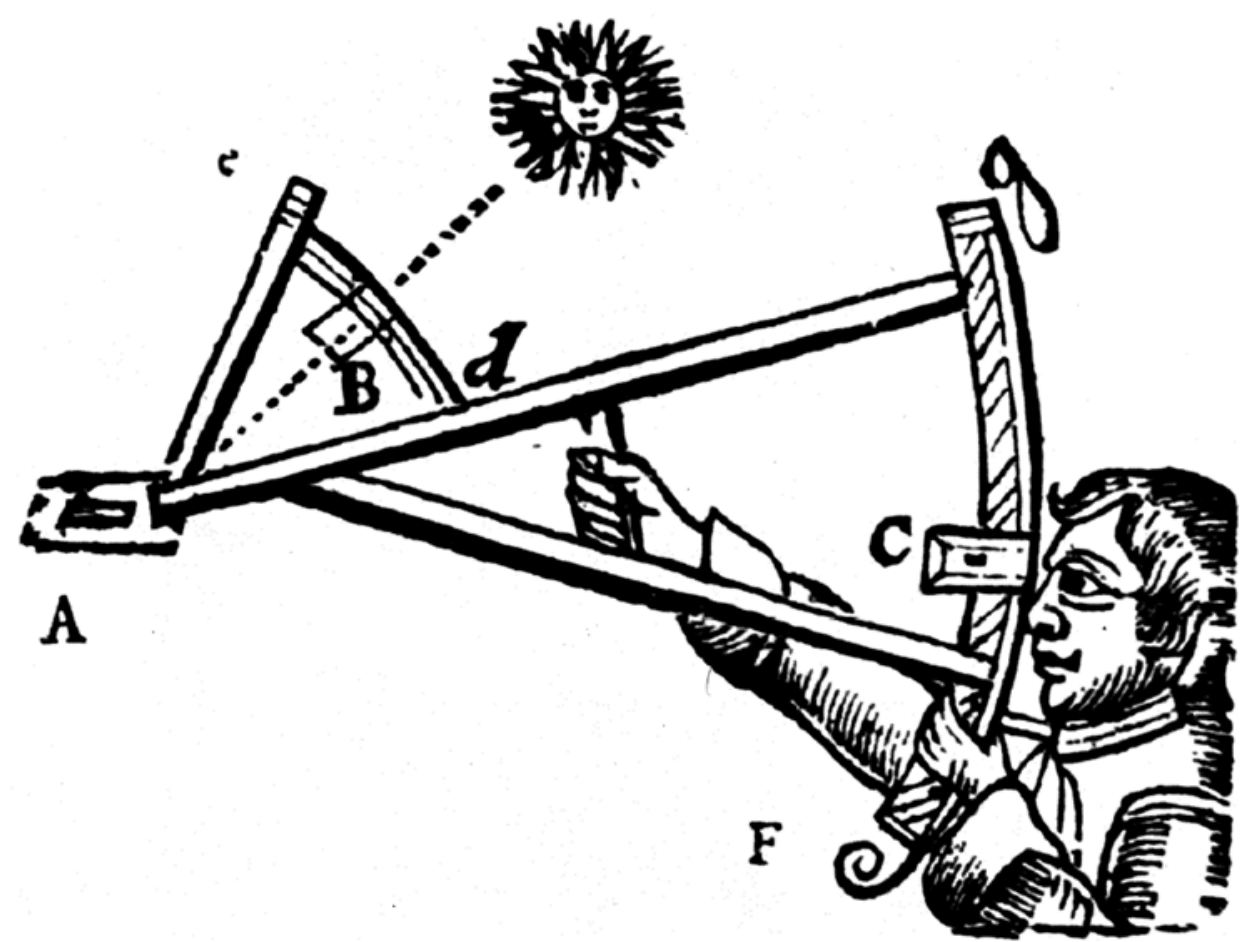

Ryc. 2. Budowa i sposób użycia back-staffu (Źródło: J. Seller, Practical Navigation, or An Introduction to the Whole Art [...], London 1730, s. 140).

Jeśli traktować znaleziony w papierach Halleya rękopis jako spisany przez Newtona i odpowiadający przedstawionemu przez niego w 1699 r. przyrządowi nawigacyjnemu, należałoby również przyjąć, że nie tylko został on „obmyślony” (contrived) przez autora Zasad, lecz także wykonany przez niego samodzielnie. Zarówno w wystąpieniu przed Towarzystwem Królewskim, jak i w opisie jego budowy nie ma żadnej uwagi dotyczącej ewentualnej pomocy ze strony rzemieślników czy wytwórców ówczesnych przyrządów nawigacyjnych. Oktant morski Newtona i inne zbliżone funkcjonalnie katadioptryczne przyrządy nawigacyjne, które zostaną omówione w ostatniej części tego artykułu, były pierwszymi, w których zastosowano optykę soczewkową w formie lunety celowniczej.

W swojej części tzw. matematycznej (łuk podziałowy z wskaźnikiem) oktant morski zachował z jednej strony pewną ciągłość z wcześniejszymi, szeroko rozpowszechnionymi w praktyce żeglarskiej, instrumentami nawigacyjnymi, takimi jak kwadrant, astrolabium żeglarskie, cross-staff (lub inaczej laska Jakuba) i w końcu back-staff (zwany także kwadrantem Davisa). Dwa ostatnie przyrządy były wykonywane ze szlachetnych gatunkach drewna (szkielet, łuki i przezierniki). Podziałki kątowe na łukach były ryte ręcznie. Cross-staff, choć był znany już w XIV w., do nawigacji został wprowadzony przez portugalskich żeglarzy dopiero w XVI w. Z kolei back-staff (Ryc. 2) został wynaleziony pod koniec XVI w. przez angielskiego podróżnika Johna Davisa (1550-1605), stąd także jego nazwa kwadrant Davisa (na kontynencie 
zwany również „angielskim”). Dokładność tych instrumentów dochodziła do kilku minut kątowych. Były one wykorzystywane w wyprawach morskich do połowy XVIII w. ${ }^{30}$

Z drugiej strony oktant morski zapoczątkował nową, królującą na morzach od XVIII w. linię wykonywanych głównie z mosiądzu (wcześniejsze rodzaje także ze szlachetnego drewna, np. hebanu) przyrządów katadioptrycznych takich, jak sekstant czy koło odbiciowe. W przypadku, wynalezionego w latach pięćdziesiątych XVIII w. przez Mayera (17231762) koła odbiciowego dokładność pomiaru, przy dodatkowym wykorzystaniu metody tzw. repetycji, wynosiła od kilkunastu nawet do kilku sekund kątowych ${ }^{31}$.

Nie wiadomo, czy oktant zbudowany przez Newtona został kiedykolwiek wykorzystany do pomiarów długości geograficznej w warunkach morskich. W październiku 1698 r. Halley wyruszył na pokładzie HMS Paramore w podróż na wody Atlantyku m.in. w celu zbadania możliwości wyznaczania długości geograficznej za pomocą kompasu ${ }^{32}$. Wrócił 11 lipca następnego roku, zanim Newton osiem dni później zapowiedział w Towarzystwie Królewskim ulepszenie „przyrządu Pana Halleya" ${ }^{33}$, którą to zapowiedź spełnił wspomnianą powyżej swoją sierpniową prezentacją własnego przyrządu - oktantu odbiciowego z podwójnym zwierciadłem ${ }^{34}$. Słowa Newtona z tej prezentacji sugerowały także posługiwanie się przez Halleya w czasie podróży jakimś bliżej nierozpoznanym dzisiaj przyrządem nawigacyjnym katadioptrycznym. Bennett uważa, że Halley mógł wykorzystać jakąś wcześniejszą wersję oktantu Newtona w czasie swojej pierwszej podróży oceanicznej (16981699). Z kolei A.D.C. Simpson sądzi, że Newton mógł przekazać swój oktant Halleyowi po jego powrocie z drugiej podróży dalekomorskiej w 1701 r., a ten wykorzystał instrument w pracach nad kreśleniem mapy Kanału Angielskiego (La Manche) ${ }^{35}$. Bez względu na rozstrzygnięcie tej kwestii na uwagę zasługuje w powyższej perspektywie niewątpliwa, choć - jak się wydaje - słabo udokumentowana, przynajmniej w odniesieniu do oprzyrządowania nawigacyjnego, współpraca między Newtonem a Halleyem, który - o czym nie można zapomnieć - był nie tylko astronomem i matematykiem, lecz także nawigatorem i kapitanem marynarki jego królewskiej mości (Wilhelma III Orańskiego).

$\mathrm{Na}$ koniec tego paragrafu warto wspomnieć o jak dotąd nierozwiązanej zagadce dość tajemniczego przyrządu astronomicznego, którego opis autorstwa Newtona, opatrzony sygnaturą Ms Add. 4005, jest przechowywany obecnie w Bibliotece Uniwersyteckiej w Cambridge ${ }^{36}$. Projekt tego przyrządu, nazywanego przez autora Zasad „kwadrantem lub sekstansem", przedstawiony został w formie odręcznej notatki w związku z zagad-

30 G.L'E. Turner, Scientific Instruments, 1500-1900: An Introduction, Berkeley - Los Angeles 1998, s. 30-33; N. de Hilster, The Spiegelboog (Mirror-Staff): a Reconstruction, „Bulletin of the Scientific Instrument Society” 2006, nr 90, s. 6-7; E. Wyka, Kwadrant morski - nowy nabytek do zbiorów Muzeum UJ, „Alma Mater” 2007, nr 96, s. 55-56.

31 Zob. J. Rodzeń, op. cit., s. 433-434.

32 Zob. A. Cook, Edmond Halley: Charting the Heavens and the Seas, Oxford 1998, s. 273-274; N.J.W. Thrower, The Three Voyages of Edmond Halley in the Paramore, 1698-1701, vol. 1, London 1981, s. 66-67.

33 RSA, SM, sygn. MS 577, k. 18r.

34 Nie posiadamy żadnej informacji co do dalszych losów przyrządu nawigacyjnego Newtona z 1699 r.

35 J. Bennett, op. cit., s. 252; A.D.C. Simpson, op. cit., s. 207. Sceptyczny wobec możliwości wykorzystania w warunkach morskich zbudowanego przez Newtona instrumentu jest z kolei Derek Howse. Nie podaje on jednak na to bardziej szczegółowych argumentów. Zob. D. Howse, Greenwich Time and the Longitude, London 1997, s. 64.

36 Cambridge University Library, Cambridge, UK [CUL], sygn. MS Add. 4005, k. 43. Transkrypcja oraz przekład anglojęzyczny tego manuskryptu znajduje się w opracowaniu: A.R. Hall, M. Boas Hall, Unpublished Scientific Papers of Isaac Newton: A Selection from the Portsmouth Collection in the University Library, Cambridge, Cambridge 1962, s. 386-391. 
nieniem pomiaru czasu astronomicznego za pomocą zegara wahadłowego i obserwacji lunetowych. Projekt Newtona przewidywał budowę trzystopowego (czyli o długości ok. jednego metra) instrumentu, za pomocą którego można by było mierzyć czas, przy dokładności przyrządu do jednej sekundy kątowej. Budową przypominał on newtonowski oktant z 1699 r. Jednak w odróżnieniu od niego projekt przyrządu z rękopisu MS Add. 4005 tworzył szczególny rodzaj lunety zaopatrzonej w niekonwencjonalne dla tamtego czasu dwie niewspółosiowe, położone jedna obok drugiej soczewki obiektywowe nacelowane na dwa zwierciadła, jedno umieszczone przy tubusie i drugie na wierzchołku żelaznego łuku. Łuk z podziałką kątową miał poruszać się prostopadle do osi tubusu dzięki specjalnej śrubie (mikrometrycznej), której obroty jednocześnie zwiększały dokładność instrumentu dziesięcio-, a nawet stukrotnie ${ }^{37}$.

Pomiary z użyciem tego instrumentu miały odbywać się na tej samej zasadzie, jak w przypadku newtonowskiego oktantu odbiciowego z 1699 r., tzn. z wykorzystaniem techniki jednoczesnej obserwacji i pomiaru odległości od siebie dwóch obiektów astronomicznych dzięki dwom zwierciadłom - jednemu ruchomemu i drugiemu nieruchomemu. Niestety, oprócz wyżej wymienionej notatki nic więcej nie wiadomo o losie tego projektu; nie wiadomo też, czy został on kiedykolwiek zrealizowany. A.R. Hall i M. Boas Hall nazwali go jedynie „poprzednikiem newtonowskiego sekstansu, opisanego w Philosophical Transactions"38, a więc omawianego tu oktantu. Jak się wydaje jednak takie dość mocne stwierdzenie nie ma zdecydowanego pokrycia w określonych przesłankach, których brakuje ${ }^{39}$. Nie wiemy nic ani o okolicznościach wykonania tej notatki, ani tym bardziej o dacie, a nawet okresie, w którym ona została spisana. Identyczność wynalazczej techniki pomiaru odległości między obiektami astronomicznymi każe jednak przypuszczać, że obydwa projekty, zrealizowana konstrukcja oktantu morskiego z 1699 r. i niezrealizowana (także przypuszczalnie) - newtonowskiego „kwadrantu lub sekstantu” powstały w nieodległej od siebie perspektywie czasowej.

\section{Przyrząd Halleya, roszczenia Hooke'a i oktanty Hadleya}

23 marca 1692 r. na posiedzeniu Towarzystwa Królewskiego Halley przedstawił własną propozycję instrumentu nawigacyjnego mającego służyć do wyznaczania szerokości geograficznej (Of an Instrument for Observing at Sea) ${ }^{40}$. Przyrząd ten składał się z tele-

37 Ibid., s. 390-391. Choć działanie śruby było zaprojektowane dla systemu dziesiętnego, po odczytach pomiarowych były one przeliczane na miarę kątową. Aby zachować stabilność przyrządu (tzn. pionowe zorientowanie płaszczyzny łuku) podczas jego trzymania ręcznego, tubus lunety został w projekcie zaopatrzony, w ustawione także pionowo dwa stabilizatory z umocowanymi na obu końcach odważnikami ołowianymi, łudząco przypominającymi współczesne stabilizatory łucznicze.

38 lbid., s. 386.

39 Na przykład Derek Whiteside, odnosząc się do rękopisu MS Add. 4005, nie wspomina w ogóle jego fragmentu z k. 43 i nie robi żadnych aluzji co do okresu, w którym ten rękopis mógłby powstać; The Mathematical Papers of Sir Isaac Newton, t. 7, 1691-1695, wyd. D.T. Whiteside, Cambridge 2008, s. xii, przyp. 8.

40 Nieopublikowana wcześniej treść wystąpienia Halleya znajduje się w: Correspondence and Papers of Edmond Halley, wyd. E.F. MacPike, Oxford 1932, s. 161-162; jego streszczenie jest zawarte w protokołach posiedzeń: tenże, s. 228. Z tego ostatniego wynika, iż za pomocą swojego przyrządu angielski astronom i żeglarz mógł wyznaczać nie tylko szerokość, ale i długość geograficzną: „Pan Halley skonstruował wersję roboczą przyrządu [...], który odbijał jeden obiekt, obserwując inny bezpośrednio w tej samej lunecie". 


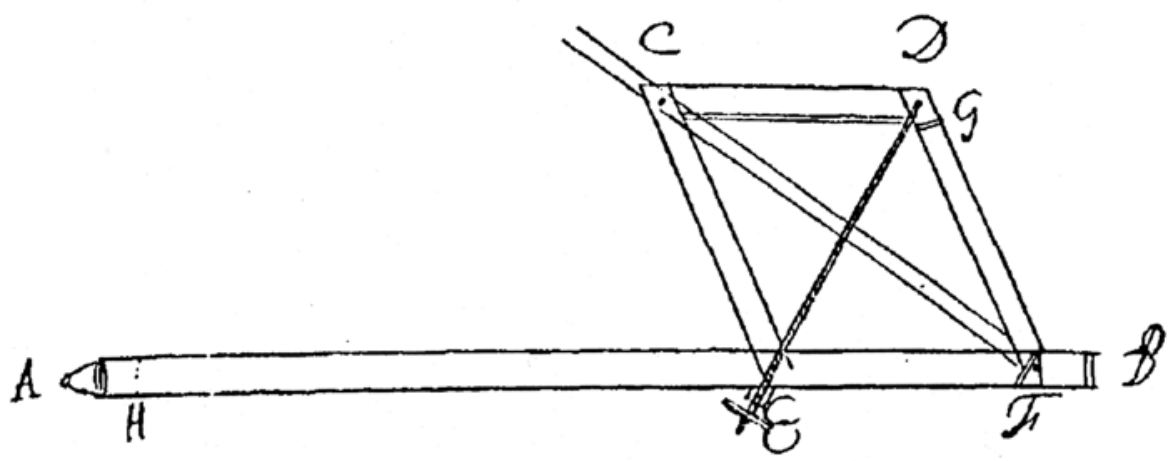

Ryc. 3. Przyrząd nawigacyjny Halleya (Źródło: Correspondence and Papers of Edmond Halley, wyd. E.F. MacPike, Oxford 1932, s. 162).

skopowego tubusu o przekroju kwadratowym, na którym, w przedniej jego części, został umieszczony szkielet o kształcie rombu z ruchomymi pantograficznie ramionami. Dzięki nacelowanemu na horyzont tubusowi (z okularem i obiektywem) oraz układowi umieszczonego w nim pół-posrebrzanego zwierciadła wraz z soczewką nacelowaną na tarczę słoneczną i przymocowaną do jednego z pionowych ramion szkieletu, można było za pomocą specjalnej śruby regulacyjnej (i tablicy cięciw) wyznaczyć wysokość Słońca (lub gwiazdy) nad horyzontem (Ryc. 3).

W idei instrumentu Halleya można doszukać się pewnych analogii technicznych, zwłaszcza z późniejszymi wariantami back-staffu (przypuszczalnie znanymi Halleyowi jako nawigatorowi), w szczególności tymi zaopatrzonymi w tzw. soczewkę Flamsteeda (Flamsteed lens), umieszczoną przez tego astronoma w latach siedemdziesiątych XVII w. w przezierniku cienia. W przyrządzie Halleya soczewka skupiająca obraz Słońca jest analogonem soczewki Flamsteeda, z kolei tubus lunetowy ze zwierciadłem jest analogonem układu przezierników horyzontalnego i obserwacyjnego w back-staffie. Również w przypadku obserwacji wysokości Słońca zarówno back-staffem, jak i przyrządem Halleya obserwator stał do niego tyłem.

Na tym samym posiedzeniu głos zabrał Robert Hooke (1635-1703) twierdząc, że on „już dawno temu wynalazł przyrząd taki, jak ten [Halleya - J.R.]"41. Rzeczywiście, zgodnie z tym zdaniem, 29 sierpnia 1666 r. jako ówczesny kurator doświadczeń Hooke przedstawił na forum Towarzystwa Królewskiego projekt przyrządu „[...] do obserwacji pozycji i odległości gwiazd stałych od Księżyca na zasadzie odbicia”. Został wtedy „zobowiązany do możliwie szybkiego (with speed) jego wykonania oraz dostarczenia wraz z nim opisu i sposobu użycia"42. Miało to się stać na kolejnym posiedzeniu Towarzystwa 12 września. Cześć historyków sądzi, że nigdy nie doszło do testów tego przyrządu w warunkach mor-

41 Cyt. za: ibid., s. 161, przyp. 1.

42 T. Birch, The History of the Royal Society [...], t. 2, London 1756-1757, s. 113. Por. także: R. Waller, The Posthumous Works of Robert Hooke, London 1705, s. 503. 


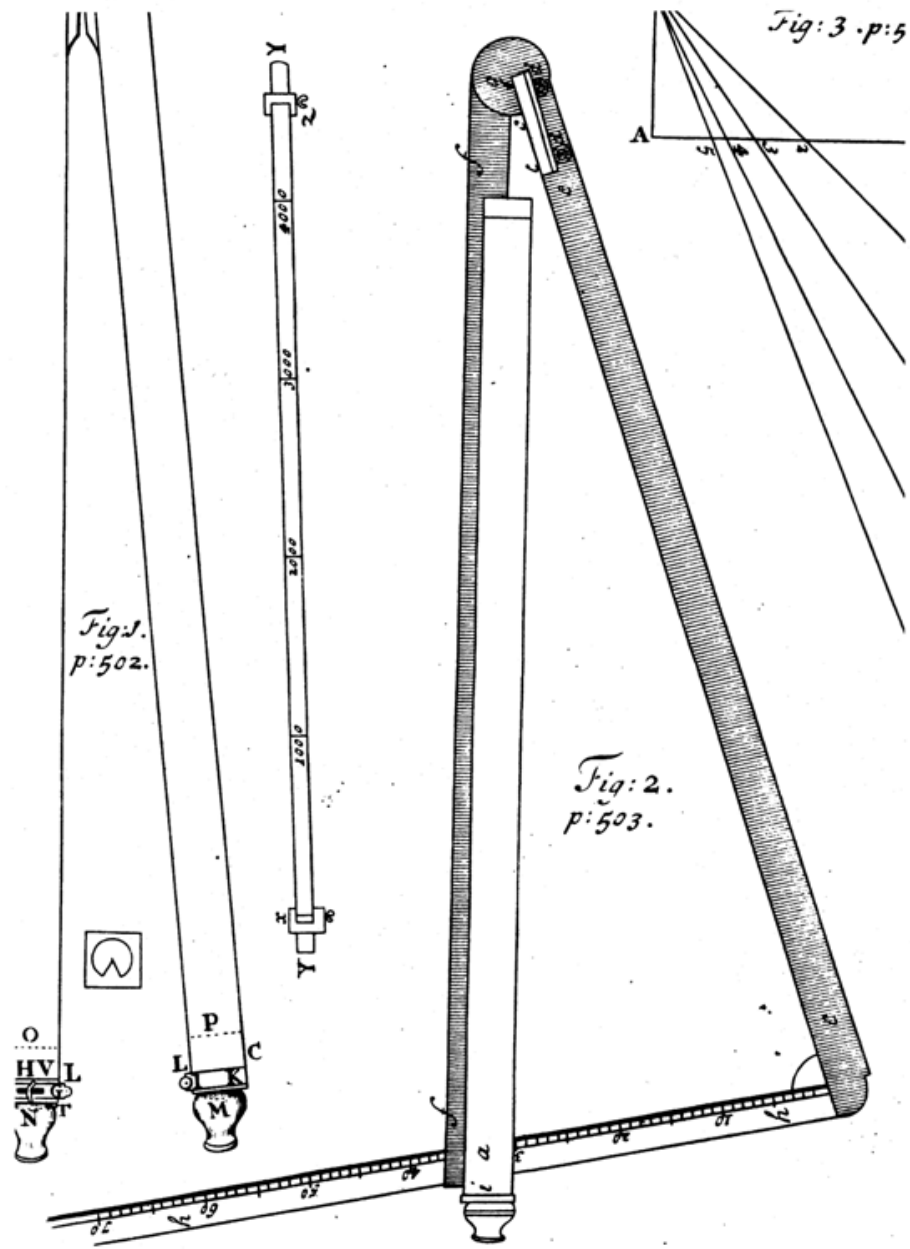

Ryc. 4. Przyrząd katadioptryczny Hooke'a. Źródło: R. Waller, The Posthumous Works of Robert Hooke, London 1705, Tabl. 11, Ryc. 2).

skich, a idea wykorzystania w nim zwierciadła została zapomniana ${ }^{43}$. Zgodnie z reprodukowaną przez Richarda Wallera w 1705 r. ilustracją (Ryc. 4) miał on kształt trójkątnej ramy złożonej z trzech drewnianych ruchomych ramion. Na ramieniu wskaźnikowym umieszczona była wzdłuż lunetka celownicza. Przy jej obiektywie i przy osi łączącej drugie ramię przymocowane zostało zwierciadło płaskie. Trzecie ramię miało rytą podziałkę kątową. Obserwator celował lunetką w kierunku horyzontu, obserwując w tym samym czasie odbity obraz ciała niebieskiego. Wtedy końcówka przyokularowa ramienia wskaźnikowego pokazywała na podziałce wysokość tego ciała ${ }^{44}$. Towarzystwa 27 VII 1670 r. przedstawił model swojego przyrządu nawigacyjnego i został przez zebranych zobowiązany do wykonania stosownych testów w warunkach morskich; T. Birch, op. cit., s. 447.

44 Por. W.F.J. Mörzer Bruyns, op. cit., s. 23; J. Bennett, op. cit., s. 252-253. 
Podobny zarzut ze strony Hooke'a, zresztą nie pierwszy wobec Newtona, spotkał także zaprezentowany przez tego ostatniego w sierpniu 1699 r. oktant morski. Na kolejnym posiedzeniu Towarzystwa Królewskiego, 25 października, w podobnym stylu, jak w przypadku instrumentu Halleya, Hooke zapewniał, iż wynalazł taki przyrząd ponad trzydzieści lat temu i zostało to odnotowane w spisanej już kiedyś wczesnej historii Towarzystwa (chodziło o pracę Thomasa Sprata z 1677 r.) ${ }^{45}$. Po tym wystąpieniu notorycznego rywala Newtona, angielski uczony już nigdy później nie powrócił do tematu budowy i wykorzystania swojego przyrządu nawigacyjnego. Przypuszczalnie również z tego powodu nie opublikował informacji o swoim wynalazku ${ }^{46}$. Był to już kolejny raz (po zakwestionowaniu prac Newtona na temat światła, sensowności budowy teleskopu zwierciadłowego, w końcu pierwszeństwa w odkryciu prawa grawitacji), kiedy roszczenia odkrywcze czy wynalazcze Hooke'a powodowały u autora Zasad wycofanie się na dłuższy czas z publicznej dyskusji naukowej.

Okres tworzenia katadioptrycznych oktantów nawigacyjnych dopełniło w 1731 r. skonstruowanie kolejnych jego typów przez angielskiego matematyka i wynalazcę Johna Hadleya (1682-1744) ${ }^{47}$. Hadley zaprezentował dwie wersje swojego oktantu na posiedzeniu Towarzystwa Naukowego 13 maja tego roku. Funkcjonowały one na tej samej zasadzie (lunetka celownicza i dwa zwierciadła). Różnica tkwiła w budowie i sposobie obserwacji. Ponieważ jeden z przyrządów Hadleya był bardzo podobny konstrukcyjnie do oktantu newtonowskiego ${ }^{48}$, tydzień później, na kolejnym posiedzeniu Towarzystwa, zauważył to publicznie sędziwy Halley. Jego oświadczenie wprowadziło konsternację w gronie zebranych, postanowiono więc odnaleźć w protokołach dawniejszych posiedzeń zapisy o oktancie Newtona. Po ich odnalezieniu stwierdzono na grudniowym posiedzeniu Towarzystwa, że nie zawiera ono żadnych szczegółów co do jego budowy i zasady działania. W tej sytuacji Halley, choć nie był w zgodzie ze wszystkimi znanymi mu faktami, przyznał publicznie, że oktant Hadleya jest konstrukcją oryginalną ${ }^{49}$.

Historycy zauważają, że rozwiązania konstrukcyjne Hadleya, w szczególności pierwszy wariant jego oktantu, który można śmiało nazwać newtonowskim, zbiegły się czasowo z podobnym projektem, zrealizowanym faktycznie, choć prawdopodobnie zupełnie niezależnie, przez amerykańskiego optyka i astronoma amatora Thomasa Godfreya (1704$1749)^{50}$ ok. 1730 r. Miał on zostać użyty, w tym do wyznaczania długości geograficznej, w czasie podróży na tzw. slupie (rodzaj małego jednomasztowego żaglowca) Trueman

45 RSA, SM, MS 577, k. 20v; T. Sprat, The History of the Royal Society of London, for the Improving of Natural Knowledge, London 1667, s. 246.

46 Por. H.C. Freiesleben, op. cit., s. 517. Pod względem konstrukcyjnym i funkcjonalnym przyrząd Hooke'a był bardziej zbliżony do oktantu Newtona, aniżeli do instrumentu Halleya. Ten ostatni przyrząd, jak to już zostało zauważone powyżej, wykazywał natomiast pewne podobieństwa do back-staffu.

47 J. Hadley, op. cit., s. 147-157. Jest interesujące, że Hadley w latach dwudziestych XVIII w., jeszcze za życia Newtona, przyczynił się do odnowienia pamięci o jego wariancie teleskopu zwierciadłowego, budując tego typu instrument o długości ok. $150 \mathrm{~cm}$ i aperturze ok. $15 \mathrm{~cm}$; por. J. Bennett, op. cit., s. 255-256.

48 Należy zauważyć podobieństwo drugiego („nie-newtonowskiego”) wariantu oktantu Hadleya do późniejszych sekstantów nawigacyjnych, budowanych od drugiej połowy XVIII wieku; por. G.L'E. Turner, op. cit., s. 265-267. Jak nazwa sugeruje, sekstant w odróżnieniu od oktantu (ze skalą kątową stanowiącą 1/8 koła podziałowego) posiadał skalę będącą 1/6 koła podziałowego, z podziałką do 120 stopni kątowych (ze względu na układ optyczny z dwoma zwierciadłami).

49 Por. J. Bennett, op. cit., s. 262-263.

50 Prywatnie Godfrey był dobrym znajomym amerykańskiego wynalazcy i jednego z ojców-założycieli Stanów Zjednoczonych Benjamina Franklina (1706-1790). 
do Jamajki i Nowej Funlandii51. Choć więc istnieją poważne wątpliwości co do praktycznego wykorzystania oryginalnego oktantu Newtona, jego wynalazcza myśl została trwale ucieleśniona najpierw w jednym z wariantów oktantu Hadleya, a potem w przyrządzie nawigacyjnym skonstruowanym na drugiej półkuli przez Godfreya.

Jak to już częściowo zostało wspomniane powyżej, oktanty, głównie typu hadleyowskiego, co prawda były spotykane w użyciu do końca XIX w., jednak już w latach siedemdziesiątych XVIII w. były stopniowo wypierane przez dokładniejsze (m.in. dzięki zastosowaniu soczewek achromatycznych w lunetkach celowniczych), choć droższe, sekstanty żeglarskie ${ }^{52}$. Układ mechaniczno-optyczny z dwoma zwierciadłami, w tym jednym ruchomym, został w nich "oddziedziczony" po wynalazku Newtona i na trwałe zapisał się kartach historii nawigacji morskiej oraz metod wyznaczania długości geograficznej.

Artykuł rozpoczęliśmy od nawiązania do XVII-wiecznych usilnych starań w poszukiwaniu skutecznej metody wyznaczania długości geograficznej na morzu i tym wątkiem go zakończymy. Swojej przygody z poszukiwaniem skutecznej metody wyznaczania długości geograficznej na morzu Newton nie zakończył w 1699 r. W czerwcu 1714 r., w reakcji na ostrą petycję kupców i żeglarzy brytyjskich skierowaną do Izby Gmin uformowała się doraźna komisja, mająca na celu zbadanie tego palącego problemu nawigacyjnego ${ }^{53}$. Jednym z ekspertów komisji, czego zresztą można było się spodziewać, został Newton (głównie jako prezes Towarzystwa Królewskiego i wybitny znawca matematyki oraz astronomii). W przygotowanym przez siebie sprawozdaniu przedstawił on m.in. zalety i słabości dotychczasowych metod wyznaczania długości geograficznej na morzu (metodę sygnałów świetlnych, odległości księżycowych, wykorzystującej zaćmienie księżyców Jowisza i zegarową), podkreślając trudności w realizacji każdej z nich ${ }^{54}$.

Sprawozdanie Newtona zawierało także propozycję ustanowienia nagrody za znalezienie skutecznej metody określania długości geograficznej oraz warunki jej przyznania. Po ich rozważeniu przez komisję parlamentarną ustalono sumę 20 tys. funtów nagrody za opracowanie metody określania długości geograficznej z dokładnością do pół stopnia kątowego, 15 tys. funtów za dokładność do dwóch trzecich stopnia i 10 tys. za uzyskanie dokładności do jednego stopnia. Wkrótce też została zatwierdzona przez królową Annę (1665-1714) ustawa o długości geograficznej (Longitude Act), a samemu Newtonowi przyszło, jako członkowi kolejnej, już ustawowej komisji (Longitude Bord), oceniać zarówno te interesujące i rokujące na pomyślną realizację, jak i te najbardziej pokrętne i dziwaczne sposoby na przezwyciężenie największej z bolączek żeglarskich tamtych czasów. Co więcej, Isaac Newton praktycznie do końca swojego długiego życia pozostał stałym ekspertem brytyjskiej Admiralicji z zakresu metod określania długości geograficznej na morzu ${ }^{55}$.

51 Zob. H.C. Freiesleben, op. cit., s. 521; W.F.J. Mörzer Bruyns, op. cit., s. 27.

52 G.L'E. Turner, op. cit., s. 32.

53 W Anglii wszyscy mieli w tym czasie w pamięci tragedię żeglarską z udziałem czterech okrętów marynarki pod wodzą, wspomnianego już admirała Cloudesleya Shovela, które w drodze do Portsmouth, na skutek błędnej oceny długości geograficznej, $22 \times 1707$ r. roztrzaskały się o skały wysp Scilly położnych niedaleko wybrzeża Kornwalii. Zginęło wtedy ok. 1500 marynarzy; zob. D. Sobel, op. cit., s. 15-16.

54 Zob. Tamże, s. 40-41; rękopisy Newtona dotyczące prac parlamentarnych nad kwestią długości geograficznej: CUL, Papers on Finding the Longitude at Sea [1697-1725], sygn. MS Add. 3972.

55 A.R. Hall, op. cit., s. 327. Por. także: List Newtona do Admiralicji z 26 VIII 1725 r.; The Correspondence of Isaac Newton, vol. 7, 1718-1727, wyd. A.R. Hall, L. Tilling, Cambridge 1977, s. 330-332. 
Stwierdziliśmy powyżej, że nie są dokładnie znane dalsze losy egzemplarza oktantu (przypuszczalnie jedynego) zbudowanego i zaprezentowanego na forum Towarzystwa Królewskiego przez Newtona w sierpniu 1699 r. Sugestia Simpsona, zgodnie z którą autor Zasad mógł przekazać Halleyowi swój oktant co najmniej na czas wykonywania przez tego ostatniego prac morskich nad mapowaniem Kanału Angielskiego, wydaje się wysoce prawdopodobna. Halley był jedynym badaczem, astronomem i zarazem praktykiem nawigatorem, do którego Newton w ostatnim okresie swojego długiego i owocnego życia miał całkowite zaufanie ${ }^{56}$. Newton z kolei zajęty obowiązkami w Mennicy Królewskiej a od 1703 r. prezesurą w Towarzystwie Królewskim, nie powrócił już nigdy do zainteresowań oktantem morskim, nawet pozostając w 1714 r. ekspertem komisji parlamentarnej zajmującej się kwestią długości geograficznej. Tym sposobem jedyny egzemplarz oktantu newtonowskiego (podobnie jak opis jego budowy i działania odnaleziony dopiero w 1742 r.) mógł pozostać pod pieczą Halleya przez długie lata, w szczególności w okresie jego pobytu na stałe od 1720 r. w Greenwich w roli (drugiego z kolei) Astronoma Królewskiego, który na co dzień posługiwał się szeregiem przyrządów obserwacyjnych i pomiarowych.

Być może w okresie pełnienia przez Halleya tej funkcji w kwestii losów oryginalnego oktantu newtonowskiego kluczową postacią był jego przyjaciel i bliski współpracownik z obserwatorium John Bevis (1695-1771). To on asystował Astronomowi Królewskiemu podczas słynnej okultacji Merkurego przez Wenus 28 maja 1737 r. To on w końcu wydał pośmiertnie Tabulae Astronomicae Halleya w 1752 r. $^{57}$ Jako asystent Halleya Bevis miał szerokie kontakty nie tyle $z$ innymi astronomami, co z wytwórcami przyrządów obserwacyjnych i pomiarowych (matematycznych), w tym również dość zażyłe relacje ze znanym w tym czasie londyńskim rzemieślnikiem Thomasem Heathem (ok. 1668-1773). Z opracowania dodatku do przekładu francuskojęzycznej pracy poświęconej przyrządom matematycznym Nicolasa Biona (1652-1733), autorstwa Edmunda Stone'a (ok. 1700-ok. 1768) dowiadujemy się ${ }^{58}$, że egzemplarz oktantu Newtona „był nie tak dawno widziany w sklepie pana Heatha "Mathematical Instrument Maker» przy ulicy Strand" 59 . „Nie tak dawno", czyli w odniesieniu do daty druku pracy Stone'a, około lat piećdziesiątych XVIII w. Należy dodać, że „był widziany” wraz z innym przyrządem, którego budowę również przypisywano Newtonowi, jednym z jego teleskopów zwierciadłowych pochodzących z lat 1668-167160. Tak więc ślad dotyczący rzekomego oktantu Newtona może prowadzić od Halleya przez Bevisa do pracowni Heatha. Podczas gdy egzemplarz teleskopu zwierciadłowego, co prawda w formie niekompletnej w stosunku do egzemplarza oryginalnego, jak

56 Do tego stopnia, że Newton powierzył Halleyowi pieczę nad mennicą w Chester w czasie wielkiej odnowy monety angielskiej pod koniec lat dziewięćdziesiątych XVII w.

57 Zob. A. Cook, op. cit., s. 355

58 E. Stone, Supplement Concerning a Further Account of Some of the Most Useful Mathematical Instruments as Now Improved, [w:] The Construction and Principal Uses of Mathematical Instruments, Translated from the French of M Bion, Chief Instrument-maker to the French King, London 1758, s. 268.

59 Por. także: E. Taylor, op. cit., s. 251. Ulica Strand leży w centrum Londynu na przedłużeniu innej arterii handlowej, Fleet Street, na której ulokowane były w tym okresie znane warsztaty wytwórców przyrządów badawczych.

60 A.R. Hall, A.D.C. Simpson, An Account of the Royal Society's Newton Telescope, "Notes and Records of the Royal Society of London" t. 50, 1996, nr 1, s. 8. 
się przypuszcza, przetrwał i jest dziś przechowywany w londyńskim Towarzystwie Królewskim, po rzekomym czy autentycznym oktancie Newtona ślad niestety później zaginął.

Jak widać z powyższego, wokół losu oryginalnego egzemplarza oktantu morskiego Newtona, zaprezentowanego na forum Towarzystwa Królewskiego w 1699 r., więcej jest w tej chwili domysłów i przypuszczeń, aniżeli twardych faktów. Simpson wyraził się o nim jako „modelu zamierzonym do zademonstrowania określonej zasady pomiaru”61. Tak więc, mówiąc współczesnym językiem motoryzacyjnym (o tzw. autach koncepcyjnych ${ }^{62}$ ) i - miejmy nadzieję - nie za daleko idącym porównaniem, był to model czy też „przyrząd koncepcyjny", którego walory techniczne i praktyczne miały dopiero zostać przetestowane w rozwijanych na jego bazie kolejnych rozwiązaniach technicznych, w jakiejś bardziej długofalowej praktyce ${ }^{63}$. O pracach z wykorzystaniem oryginalnego oktantu morskiego Newtona niewiele nam wiadomo. Jednak jego myśl inżynierska, która przez współczesnych została praktycznie niemal całkowicie zapomniana i wciąż czeka na bardziej pogłębione studium, wyrażająca się także w omawianym tutaj wynalazczym rozwiązaniu, została faktycznie ucieleśniona w późniejszych jego wersjach konstrukcyjnych autorstwa Johna Hadleya i Thomasa Godfreya.

\section{Bibliografia}

\section{Źródła archiwalne}

Cambridge University Library, Cambridge, UK, Papers on Finding the Longitude at Sea [1697-1725]:

sygn. MS Add. 3972, cudl.lib.cam.ac.uk/view/MS-ADD-03972/1, [dostęp 14.10.2019];

sygn. MS Add. 4005, cudl.lib.cam.ac.uk/view/MS-ADD-04005/131, [dostęp 14.10.2019].

King's College, Cambridge, UK, Keynes [Keynes Collection], sygn. MS 130.07.

Royal Society Archive, London, Sir Hans Sloane's Minutes Books of the Royal Society Meetings, 1699-1702, sygn. MS 577, ttp.royalsociety.org/ttp/ttp.html?id=dff3463f-0894-43ba-bfe4-f994ce7989a4\&type=book [dostęp 14.10.2019].

The Newton Project, red. Rob Iliffe; Scott Mandelbrote, Faculty of History, Oxford, UK, www.newtonproject.ox.ac.uk [dostęp 14.10.2019].

\section{Źródła drukowane}

Birch T., The History of the Royal Society [...], t. 2, London 1756-1757.

Correspondence and Papers of Edmond Halley, wyd. E.F. MacPike, Oxford 1932.

61 A.D.C. Simpson, op. cit., s. 207.

62 Auto koncepcyjne jest pojazdem w wariancie studyjnym opracowanym przez producenta lub na jego zlecenie, mającym na celu zaprezentowanie możliwości projektanckich, technologicznych i stylistycznych. Auto koncepcyjne wyznacza przyszłe trendy projektowania modeli użytkowych.

63 Howse słusznie zauważa, że szersze nagłośnienie projektu oktantu przez Newtona (np. przez publikację na łamach „Philosophical Transactions”), a nie jedynie jego prezentacja na forum Towarzystwa Królewskiego, mogłoby się przyczynić do wcześniejszego wykorzystania instrumentu w praktyce nawigacyjnej; por. D. Howse, op. cit., s. 64 . 
Fatio de Duillier N., Lineae brevissimi descensus investigate geometrica duplex, Londini 1699.

Hadley J., The Description of a New Instrument for Taking Angles, „Philosophical Transactions of the Royal Society of London" t. 37, 1731, nr 420, s. 147-157, DOI 10.1098/ rstl.1731.0025.

Hall A.R., Boas Hall M., Unpublished Scientific Papers of Isaac Newton: A Selection from the Portsmouth Collection in the University Library, Cambridge, Cambridge 1962.

Holmes M.[R.], A Narrative Concerning the Success of Pendulum Watches at See for the Longitude, „Philosophical Transactions” t. 1, 1665, s. 52-58.

Newton I., A True Copy of a Paper Found, in the Hand Writing of Sir Isaac Newton, among the Papers of the Late Dr. Halley, Containing a Description of an Instrument for Observing the Moon's Distance from the Fixt Stars at Sea, „Philosophical Transactions of the Royal Society of London" t. 42, 1742, nr 465, s. 155-156, DOI 10.1098/ rstl.1742.0039.

Newton I., A New and Most Accurate Theory of the Moon's Motion [...], London 1702.

Newton I., Lunae Theoria Newtoniana, [w:] D. Gregory, Astronomiae Phisicae at Geometricae Elementa, Oxoniae 1702, s. 332-336.

Sprat T., The History of the Royal Society of London, for the Improving of Natural Knowledge, London 1667.

The Correspondence of Isaac Newton, vol. 4, 1694-1709, wyd. J.F. Scott, Cambridge 1967.

The Correspondence of Isaac Newton, vol. 7, 1718-1727, wyd. A.R. Hall, L. Tilling, Cambridge 1977.

The Mathematical Papers of Sir Isaac Newton, t. 7, 1691-1695, wyd. D.T. Whiteside, Cambridge 2008.

Waller R., The Posthumous Works of Robert Hooke, London 1705.

\section{Literatura przedmiotu}

Bennett J., Catadioptrics and Commerce in Eighteenth-Century London, „History of Science" t. 44, 2006, nr 2, s. 247-278, DOI 10.1177/007327530604400205.

Cook A., Edmond Halley: Charting the Heavens and the Seas, Oxford 1998.

Cotter C.H., The Mariner's Sextant and the Royal Society, „Notes and Records of the Royal Society of London" t. 33, 1978, nr 1, s. 23-36, DOI 10.1098/rsnr.1978.0002.

da C. Andrade E.N., Two Historical Notes, „Nature” t. 135, 1935, nr 3410, s. 359-360, DOI 10.1038/135359a0.

de Hilster N., The Spiegelboog (Mirror-staff): a Reconstruction, „Bulletin of the Scientific Instrument Society" 2006, nr 90, s. 6-16.

Freiesleben H.C., Newton's Quadrant for Navigation, „Vistas in Astronomy” t. 22, 1979, nr 4, s. 515-522, DOI 10.1016/0083-6656(78)90043-0.

Hall A.R., Isaac Newton: Adventurer in Thought, Cambridge 1992.

Hall A.R., Simpson A.D.C., An Account of the Royal Society's Newton Telescope, „Notes and Records of the Royal Society of London" t. 50, 1996, nr 1, s. 1-11, DOI 10.1098/ rsnr.1996.0001.

Howse, D., Greenwich Time and the Longitude, London 1997.

Huxley G.L., Two Newtonian Studies, I. Newton's Boyhood Interests, „Harvard Library Bulletin" t. 13, 1959, s. 348-354. 
Kollerstrom N., Newton's Forgotten Lunar Theory: His Contribution to the Quest for Longitude, Santa Fe 2000.

Kollerstrom N., Yallop B.D., Flamsteed's LunarData, 1692-95, Sent to Newton, , Journal for the History of Astronomy" t. 26, 1995, nr 3, s. 237-246, DOI 10.1177/002182869502600303.

Levenson T., Newton and the Counterfeiter. The Unknown Detective Career of the World's Greatest Scientist, London 2011.

Manuel F., Portret Izaaka Newtona, Warszawa 1998.

Merton R.K., Teoria socjologiczna i struktura społeczna, tłum. E. Morawska, Warszawa 1982.

Mörzer Bruyns W.F.J., Sextants at Greenwich: A Catalogue of the Mariner's Quadrants, Mariner's Astrolabes, Cross-staffs, Backstaffs, Octants, Sextants, Quadrants, [...] in the National Maritime Museum, Greenwich, Oxford 2009.

Rodzeń J., Na tropie widma. Geneza i ewolucja spektroskopu optycznego w latach 1810 1860, Kraków 2013.

Seller, J., Practical Navigation, or An Introduction to the Whole Art [...], London 1730.

Sobel D., W poszukiwaniu długości geograficznej, tłum. J. Bieroń, Poznań 1998.

Simpson A.D.C., The Early Development of the Reflecting Telescope in Britain, nieopublikowana praca doktorska, University of Edinburg 1981.

Šíma Z., Prague Sextants of Tycho Brahe, „Annals of Science” t. 50, 1993, nr 3, s. 445-453, DOI 10.1080/00033799300200331.

Stone E., Supplement Concerning a Further Account of Some of the Most Useful Mathematical Instruments as Now Improved, [w:] The Construction and Principal Uses of Mathematical Instruments, Translated from the French of M Bion, Chief Instrumentmaker to the French King, London 1758.

Taylor E.G.R., The Mathematical Practitioners of Tudor and Stuart England, London 1954. The Quest for Longitude, red. W.J.H. Andrewes, Cambridge, Mass. 1996.

Thrower N.J.W., The Three Voyages of Edmond Halley in the Paramore, 1698-1701, vol. 1, London 1981.

Turner G.L'E., Scientific Instruments, 1500-1900: An Introduction, Berkeley - Los Angeles 1998.

Weekley E., An Etymological Dictionary of Modern English, vol. 2, L-Z, New York 2012.

Werner J., Nova translatio primi libri geographiae Cl. Ptolomaei [...], Nürnberg 1514.

Westfall R.S., Never at Rest. A Biography of Isaac Newton, Cambridge 1980, DOI 10.1017/ CBO9781107340664.

Włodarczyk J., Księżyc w nauce i kulturze Zachodu, Poznań 2012.

Wyka E., Kwadrant morski - nowy nabytek do zbiorów Muzeum UJ, "Alma Mater" 2007, nr 96 , s. 55-56.

dr hab. Jacek Rodzeń, prof. UJK pracuje w Instytucie Historii Uniwersytetu Jana Kochanowskiego w Kielcach. Interesuje się historią nauki i techniki, w szczególności dziejami przyrządów naukowych; a także historią filozofii i dziejami relacji nauka-religia.

e-mail: j.rodzen@ujk.edu.pl

Data zgłoszenia artykułu: 26 listopada 2019

Data przyjęcia do druku: 6 marca 2020 